\title{
EVALUATION OF ANTI-INFLAMMATORY ACTIVITY OF PLANT RIVEA ORNATA
}

\author{
*Sharma Vaishali J. ${ }^{1}$, Patel Piyush M. ${ }^{2}$, \\ ${ }^{1}$ Reaserch scholar, Pharmaceutical Science, Singhania University, Pacheri Bari, Junjhunu, Rajsthan \\ ${ }^{2}$ Professor Shri B.M.Shah College of pharmaceutical education and reaserch, Modasa \\ *Corresponding author's email: vaishalisharma84@gmail.com
}

Received 04 Dec 2012; Review Completed 12 Jan 2013; Accepted 12 Jan 2013, Available online 15 Jan 2013

\begin{abstract}
The aim of present study was to explore the probable anti -inflammatory effect of methanolic extract obtained from the plant Rivea ornata. Anti- inflammatory activity was studied by Carrageenan induced rat paw edema. The extract was administered orally in dose of 200 and $400 \mathrm{mg} / \mathrm{kg} /$ body weight to healthy animals. These extract showed a greater anti inflammatory effect comparative to standard drug Indomethacin.

Keywords: Arial part, Rivea ornata, Anti-inflammatory, Indomethacin
\end{abstract}

\section{INTRODUCTION}

The Phag, Rivea ornata (Family- Solanaceae) is one of unique Rivea species widely spread in tropical and subtropical countries ${ }^{1-2}$. A woody climber branchless stout, white-tomentose. Leaves ovate-cordate 3-5 in. diam. often broader than long, glabrous above, white silky-tomentose beneath while young; petiole 1-2 in. Flowers large, white, in short, mostly 3 -fid. Peduncles; bracts $1 / 2$ in. Fruit $2 / 3$ in. diam., indehiscent, globose, shining, yellow-brown, nearly dries $^{3-5}$. Rivea ornata seed oil was found to contain 12, 13epoxy-octadec-cis-9-enoic acid (vernolic acid, 22.0\%) along with the other normal fatty acids like palmitic acid (24.2\%), stearic acid (8.9\%), oleic acid (17.1\%) and linoleic acid $(27.8 \%)^{6-9}$. Juice of the plant-used topically in hemorrhagic diseases and piles ${ }^{10}$. The plant is not studied for anti-inflammatory activity. This study was aimed at providing pharmacologic basis for its folkloric use in inflammation and other species of Rivea were found to have anti- inflammatory activity. Based on this attempt has been made to evaluate the inflammation potency of Rivea ornata.

\section{MATERIALS AND METHODS}

\section{Plant material}

The plant material was collected from the Tripura in the month of May 2011. The aerial parts were separated, dried, coarsely powdered passed through sieve no 40 and stored in a closed container for successive extraction.

\section{Preparation of extract}

The powdered plant material (450) was repeatedly extracted in a $5000 \mathrm{ml}$ round bottomed flask with $2000 \mathrm{ml}$ solvents starting with petroleum ether, chloroform, methanol and water. The reflux time for each solvent was 40 cycles. The methanolic extract was cooled at room temperature and evaporated to dryness under reduced pressure in rotary evaporator ${ }^{11}$.

\section{Acute toxicity study}

Doses of $30,100,200,400,1000,2000$, and $5000 \mathrm{mg} / \mathrm{kg}$ of extracts were administered orally to mice. The extract was given at doses of 200 and $400 \mathrm{mg} / \mathrm{kg} /$ day of body weight. All the animals found to be safe at doses of $5000 \mathrm{mg} / \mathrm{kg}$. Mice were then observed for incidence of mortality or any sign of toxicity upto $24 \mathrm{~h}$. The dosing schedule was followed as per OECD (Guideline 425) ${ }^{12}$

\section{Animals}

For Carageenan induced hind paw edema Albino Wistar rats weighing between 150-200 $\mathrm{g}$ were divided into four groups of six animals each; Control (group 1) animals were administered saline, Group 2 animals were administered the methanolic extract lower dose, 200 $\mathrm{mg} / \mathrm{kg}$, Group 3 animals were administered the methanolic extract higher dose, $400 \mathrm{mg} / \mathrm{kg}$, Group 4 animals were administered the Indomethacin $(5 \mathrm{mg} / \mathrm{kg})$.

\section{Drug and chemicals}

The methanolic extract of plant Rivea ornata was reconstituted using 0.5\% w/v Sodium Carboxy Methyl Cellulose (SCMC). The suspension was freshly prepared before use. Carageenan from Sigma Labs and all other chemicals, reagents used were of analytical grade.

\section{Evaluation of anti-inflammatory activity}

For Carageenan induced hind paw edema Albino Wistar rats weighing between 170-200 $\mathrm{g}$ were divided into four groups of six animals each; Control (group 1) animals were administered saline orally for seven days, Group 2 animals were administered methanolic extract, smaller dose, $200 \mathrm{mg} / \mathrm{kg}$ orally for seven days, Group 3 animals were administered the methanolic extract of plant higher dose, $400 \mathrm{mg} / \mathrm{kg}$ orally for seven days, Group 4 animals were administered the Indomethacin $5 \mathrm{mg} / \mathrm{kg}$ orally for seven days as a standard drug ${ }^{13-15}$. Acute inflammation was induced in rats of all the groups were injected $0.1 \mathrm{ml}$ of Carrageenan $(1 \%)$ in normal saline into sub-planter area of right hind paws of rats. On the seventh day, the drugs were given orally $1 \mathrm{~h}$ prior to Carageenan injection. Paw volume was measured by mercury plethysmograph at 0 and $3 \mathrm{~h}$ after the Carrageenan injection ${ }^{16-17}$. Mean increase in the paw volume was measured and percentage inhibition was calculated.

Percentage inhibition $=100(1-\mathrm{Vt} / \mathrm{Vc})$; where, $\mathrm{Vt}=$ edema volume in control and $\mathrm{Vt}=$ edema volume in test/standard compound. 
The results show that methanolic extract at the dose of 400 $\mathrm{mg} / \mathrm{kg}$ has significant reduction in the Carageenan induced paw oedema are given in Table 1. Extract of Rivea ornata at $200 \mathrm{mg} / \mathrm{kg}$ body weight per day when given orally as a suspension the paw volume were reduces by $51.35 \%$ whereas in case of methanolic extract of at $400 \mathrm{mg} / \mathrm{kg}$ body weight per day shows 75.90 inhibition after $3 \mathrm{~h}$ which indicate that effect manner. So $400 \mathrm{mg} / \mathrm{kg}$ dose methanolic extract exhibiting anti-inflammatory effect against acute inflammation.

Table 1: Effect of Rivea ornata leaves extracts on Carrageenan-induced paw edema in rats.

Results were expressed as Mean SEM, ${ }^{*} \mathbf{P}<0.001$ by Student's t-test; $\mathbf{P}<0.05$ by Student's t-test, $\mathrm{N}=6$ animals per group.

Carageenan induced inflammation in rats is one of the

From this investigation it may be concluded that the most suitable acute model to screen anti-inflammatory methanolic extract of aerial parts of plant Rivea ornata

\begin{tabular}{|c|c|c|c|c|c|c|c|c|}
\hline & & Inflammation & $\Delta$ in $\mathrm{ml})$ & & & & & \\
\hline Treatments & $\begin{array}{l}\text { Dose } \\
(\mathrm{mg} / \mathrm{kg})\end{array}$ & $0 \min$ & $15 \mathrm{~min}$ & $30 \mathrm{~min}$ & $60 \mathrm{~min}$ & $120 \mathrm{~min}$ & $180 \mathrm{~min}$ & $\begin{array}{l}\text { Percent } \\
\text { inhibition } \\
\mathrm{Vt}\end{array}$ \\
\hline control & 0 & $0.46 \pm 0.008$ & $0.59 \pm 0.007$ & $0.78 \pm 0.01$ & $0.79 \pm 0.01$ & $0.87 \pm 0.005$ & $0.95 \pm 0.005$ & Vc 0.74 \\
\hline $\begin{array}{l}\text { Methanolic } \\
\text { Extract }\end{array}$ & 200 & $0.43 \pm 0.01$ & $0.36 \pm 0.009^{*}$ & $0.35 \pm 0.005 *$ & $0.34 \pm 0.008^{*}$ & $0.32 \pm 0.01$ & $0.36 \pm 0.007 *$ & 51.35 \\
\hline $\begin{array}{l}\text { Methanolic } \\
\text { extract }\end{array}$ & 400 & $0.42 \pm 0.008^{*}$ & $0.19 \pm 0.01$ & $0.13 \pm 0.007 *$ & $0.12 \pm 0.01$ & $0.11 \pm 0.008^{*}$ & $0.10 \pm 0.008^{*}$ & 75.90 \\
\hline Indomethacin & 5 & $0.48 \pm 0.007$ & $0.44 \pm 0.007$ & $0.42 \pm 0.01$ & $0.40 \pm 0.08$ & $0.37 \pm 0.007$ & $0.35 \pm 0.009$ & 79.72 \\
\hline
\end{tabular}

agents. The development of Carageenan induced oedema is biphasic, the first phase is attributed to the release of histamine, 5-HT, and kinin, while, the second phase is release of prostaglandin. The observed effect may be due to inhibition of phlogistic mediators, antagonizing their interaction with their respective receptors or it may be due to general mechanism like increasing the membrane stability in the cell.

\section{CONCLUSION}

\section{REFERENCES}

1. Bhattacharya P.K.,'Studies on Ipomea wolcottiana JN Rose' An arboreal morning glory in Indian Park And Garden, Bardwan University, Journal of Science, vol.2, p.49-56, 1985.

2. Govil CM "Morphological studies in family Convolvulaceae vascular anatomy of the flower", Journal proceeding of the Indian academy of science, vol.75,p.271-282,1972

3. Wilkin P. "morphological cladistic analysis of the Ipomea ", Journal of Kew Bulletin, vol.54,p.853-876,1999.

4. Singh.K.K."Ethnobiology in human welfare" $4^{\text {th }}$ international congress of ethnobiology,Lukhnow,U.P.,p.83,1994

5. Rao..N.; Salam.M.A. "Hyperparasites on rust fungi", Journal of Science and culture, vol.25, p601-603, 1960.

6. Thomson, W.A.R., 1978. Medicines from the Earth. Maidenhead, United Kingdom. McGraw-Hill Book Co.

7. Stockwell, C., 1988. Nature's pharmacy. London, United Kingdom. Century Hutchinson Ltd.

8. Gerhartz, W., Y.S. Yamamota, F.T. Campbell, R. Pfefferkorn and J.F. Rounsaville, 1985. Ullmann's Encyclopedia of Industrial.

9. Kallappa M. Hosamani, Raghavendra M. Sattigeri,P.G. Department of Studies in Chemistry, Karnatak University, Pavate nagar, Dharwad 580 003, India studied Industrial utilization of Rivea ornata seed oil: a moderate source of vernolic acid, Industrial crop and product,vol.12, issue 2, Aug.2000, pp. 93-96 showed anti-inflammatory effects, similar to those observed for non-steroidal drug such as Indomethacin. It is important to point out that the phytochemical analysis showed the presence of flavonoids and this might be responsible for anti-inflammatory activity. Further investigations are under process in our laboratory to isolate and characterize the specific active components of the plants extract which is responsible for observed pharmacological actions.

10. C.P.Kher, Indian Medicinal Plants, an illustrated dictionary, Springer; pg no. 552

11. Alziro de Amorin, Helcio R Borba, Jorge PP Carauta, Daise Lopes and Maria AC Kaplan, Anthelmintic activity of the Latex of Ficus species, J Ethnopharmacology, 1999, 64, 255-258.

12. OECD guideline (425) for the testing of chemicals: Guidence document on acute oral toxicity, Environmental health And Safety Monograph Series On Testing and Assesment.2000.

13. Olajide, O.A., J.M. Makinde and S.O. Awe, 1999. Effects of the aqueousextract of Bridelia ferruginea stem bark on carrageenaninduced oedema and granuloma tissue formation in rats and mice. Olumayokun, 66: 113-117.

14. Viana GSB,MAM Bandeira and FJA Matos, Analgesic and antiinflammatory effects of chalcones isolated from Myracrodruon urundeuva Allemao, Phytomedicine,2003, 10 189-195

15. Akindele AJ and OO Adeyeni, Anti-inflammatort activity of the aqeous leaf extract of Bryocarpus coccineus, Fitoterapia, 2007,78, 25-28.

16. Venkatesa Perumal, $R$ Adiraj $M$ and Shanmuga Pandiyan P, Synthesis, analgesic and anti-inflammatory evaluation of substituted 4-piperidone, Indian Drugs 2001, 38,156.

17. Brooks PM and Day RO, Non-steroidal anti-inflammatory drugs: Difference and similarfities, N Engl J Med, 1991,324,1716-1725. 